\title{
Individualism and Collectivism in Taiwan
}

by Abbas J. Ali, Monle Lee, Yi-Ching Hsieh and Krish Krishnan

\section{The Authors}

Abbas J. Ali is Professor of Management, C, Indiana University of Pennsylvania, Indiana, PA 15705, USA.

Monle Lee is Professor of Marketing, School of Business and Economics, Indiana University South Bend, South Bend, IN 46615, USA.

Yi-Ching Hsieh is in the Department of Business Administration, Soochow University, 56, Kuei-Yang St., Sec. 1, Taipei 100, Taiwan.

Krish Krishnan, Professor of Marketing, Eberly College of Business and Information Technology, Indiana University of Pennsylvania, Indiana, PA 15705, USA.

\section{Introduction}

While there is a consensus among researchers that cultural values have unique qualities in the context of their respective cultures, some tend to argue that, within the workplace, these qualities are not without deficiencies. Waterman (1984) identifies four qualities for individualistic personality: a sense of personal identity, self-actualisation, an internal locus of control, and principles moral reasoning. Nevertheless, Waterman points out that an individualistic person may not be in a position to deal competently with the world or can easily overcome alienation. Similarly, Hofstede $(1980,1983)$ identifies categories of cultural values, their applications in organisations and the risk of such application if applied abroad. Cultural values have evolved gradually and are embedded in the collective memory of the people of a particular society. These values become a standard of conduct. Nevertheless, once such a standard is applied in dealing with other cultural groups, it is certain that undesired consequences take place. In management and organisation, for example, the failure of transferring western management approaches to other cultures is often attributed to the lack of understanding that these management techniques were based on a different frame of mind and different cultural assumptions. Hofstede (1999) states that management processes are embedded in cultural values and consequently differ from society to society, but within each society show strong continuity.

Researchers have asserted that the study of the individualism-collectivism (I/C) dimension provides valuable insight into cultural differences and orientations. Triandis (2004), for example, argues that the I/C dimension is the most important factor in studying cultural differences. Similarly, Oyserman, Coon, and 
Kemmelmeier (2002) indicate that the I/C dimension provides a powerful explanatory tool for understanding the variability in the behaviour of individuals in different parts of the world. The significance that has been attached to I/C stems from the fact that the I/C dimension makes up a portion of a culture's core set of values and serves as organising principles for both interpersonal and intrapersonal relationships (Williams, 2003). This research is designed to study the I/C dimension among Taiwanese managers and explores their decision style tendencies. The objectives are to determine whether or not there are differences among Taiwanese managers on $\mathrm{I} / \mathrm{C}$ measures and to investigate the relationships between decision styles and I/C.

\section{Cultural Orientations}

The literature on I/C places considerable emphasis on an important cultural reality: individuals and society alike can simultaneously hold I/C beliefs and attitudes (Kim, 1994; Sinha \& Tripathi, 194; Wagner \& Moch, 1986). Most scholars agree that in collective culture group welfare, group goals, interdependence, and relationships take priority in individual life and conduct. People in collective societies give special attention to social relationships and spend a great deal of time getting to know the people around them (Ali, 2004; Choi, Nisbett \& Norenzayan, 1999). In an individualistic society, persons are concerned with pursuing their goals and are not preoccupied with group welfare. They seek to maintain their independence from others by attending to the self and by discovering and expressing their unique attributes (Markus \& Kitayama, 1991). Individuals in these societies tend to be assertive, independent, and seek privacy and self-gratitude through self-reliance, control, and the persistent pursuit of activities that optimise personal gain and pleasure. The nature of relationships in a collective society induces individuals to be conformist to primary group norms and beliefs and to assume responsibilities that sustain in-group relationships and thus improve his/her status in the group (Ali, Taqi \& Krishnin, 1997). Kim (1994) argues that in a collective society, socialisation places emphasis on compliance, obedience, and responsibility. Consequently, collectivism entails the need to preserve the primary group harmony and will lead to a more egalitarian assignment of rewards and punishments for individual contributions to a group product (Bond, Leung, and Wan, 1982). In contrast, socialisation in an individualistic society emphasises assertiveness, autonomy, achievement, and self-reliance. Individuals seek to maximise their rewards and to secure professional and personal progress. Nevertheless, collective efforts may appeal to individualists if they can result in outcomes that satisfy personal interests (Wagner \& Moch, 1986).

Researchers have often debated circumstances that lead to the disposition toward individualism or collectivism. Ji, Nisbett and Peng (2000) suggest that socioeconomic conditions in the West have historically encouraged individualistic orientations. In contrast, the social structure in East Asia reinforces collective tendencies. This is because these societies, until quite recently, were based on agri- 
cultural economies in which cooperation was crucial and hierarchical political organisation required obedience. Hofstede (1994) indicates that individualism prevails in developed and Western countries and collectivism in developing and Eastern countries. Others seem to highlight the role of culture in the conceptualisation of self. Markus \& Kitayama (1991) argue that the way most people naturally perceive and understand the world is rooted in their self- perceptions and self-understandings that are themselves constrained by the patterns of social interactions pertaining to a given culture.

An important work related attitude is decision style. Decision styles have been found to differ across cultures and organisations (Heller \& Wilpert, 1979). Hui (1988) suggests that the I/C dimension influences decision styles and that in a collective culture there is a reliance on group decisions. Similarly, Bond, et al. (1982) argues that collectivism entails the need to preserve group harmony and consequently results in using styles that facilitate achieving such a goal. In an organisational setting, managers may subscribe to a particular decision style (e.g. a dominant one). This, however, does not preclude them from utilising various other styles. Most recent research in cross-cultural studies of management and organisation asserts that leaders can adapt different decision styles, depending on the pattern of organisation and individual characteristics (Ali, Azim \& Falcone, 1993; Blyton, 1984; Yukl, 1981), and cultural values (Hofstede, 1980). The result of such research appear to suggest that in general there is a correspondence between the I/C dimension and decision styles. For example, in a collective culture, there is an emphasis on decision styles that maintain and reinforce consensus (e.g. consultative, participative) whereas, in an individualistic culture, styles that maximise or serve individual interests are adopted.

Taiwan has one of the most rapidly growing economies in East Asia. The country, however, suffers from a slowing growth in population. Indeed, the slow growth in population rate is changing the age structure of the society. About $8.8 \%$ of the population were aged 65 or over in 2000, compared with only 6.2 in 1990 and 2.5 in 1960 (Economist Intelligence Unit, 2004). Further complicating the economic situation is the fact that Taiwan's economy is highly dependent on its involvement in international trade. That is, economic development in Taiwan is highly sensitive to market conditions abroad. Lin and Szenberg (1988) have found that, prior to 1986, Taiwanese-based firms' exports were profitable because their unit export values were higher than their unit labour costs. This aspect, however, changed after 1986. Many firms experienced a loss in their exports as unit labour costs increased faster than unit export values. This change induced Taiwanese-based firms to engage in capital-intensive operations at home and to pursue labour-intensive ones abroad. As such, the share of labour-intensive industries in manufacturing output decreased from $43 \%$ of the total GNP to $27 \%$ between 1981 and 1996. By contrast, the share of technology-intensive industries increased from 20 to $38 \%$ during the same period (Kuo \& Liu, 1999). 
In reviewing the literature on values and work orientations in Taiwan, Wu (2004) found inconsistent results. For example, he cited some studies which concluded that Taiwanese society is gradually transforming into one that emphasises individual need more and collective needs less. He speculates that individual needs are more possibly in tune with the "modern values" (e.g. autonomy, exhibition, etc.) of Taiwanese society. The society, he asserted, is currently placing priority on autonomy and change and less on order and obedience. Nevertheless, he cites studies that show that the traditional values of harmony and familism are persistent. He concludes that, despite the rise of individualism, indigenous collectivistic values survive and co-exist with modernity. Similarly, Chi (1999) indicates that despite economic development in Taiwan, individuals still belong to sets of overlapping social networks and that subordinates and managers alike value social closeness and trustworthiness at the workplace. Previously, Hofstede (1980) found that Taiwanese employees showed a low level of individualism and large power distance. Oyserman, Coon and Kemmelmeier (2002) have found that Taiwanese subjects are low on individualism and higher on collectivism relative to Americans. Yi, Chang and Chang (2004) have asserted that Taiwan is a paternalistic society and that the upbringing of children reinforces obedience and external punishment. Their results demonstrate that value transmission from the parent's generation to child's generation in Taiwan is likely to continue despite the constant challenge from the modernisation process.

The transformation of Taiwan into an industrial society that has taken shape in the last thirty years is certain to influence the outlook of the majority of the population, especially the business people. It is more likely that most of the expected changes will take place in technology, structure, and design approaches. It is in these areas, rather than in cultural values, that industrialisation has the most notable effect. Sinha, Kao and Wilpert (1999) argue that in Asia there has been an extraordinary adaptation of the requirements of work and modern technology to specific elements of culture. This has produced a synergistic blend of traditional indigenous roots and modern techniques. Cultural adaptation of technological innovation and modern development methods, while highlighting the acceptance and desirability of the economic progress, underscore the depth of cultural values and norms that govern personal aspirations, relationships and behaviour. That is, a closer examination of human behaviour and practice is likely to highlight cultural effects. This proposition means that the cultural factor will have the most bearing upon modes of interpersonal relationships and conduct (England, Negandhi \& Wilpert, 1979; Hofstede, 1999). Therefore, it is expected that Taiwanese managers exhibit work values and orientations that are in tune with collectivistic tendencies and traditional values. In terms of decision styles, the literature review reveals that researchers have seldom directly addressed decision style and practice in Taiwan. Nevertheless, it is possible to suggest that managerial decision styles will be more in line with traditional collective values. As Hofstede (1980) has asserted, in Taiwan and other Asian countries, there is a situ- 
ation where subordinates in a group can always influence the leader and the leader shows obligations towards subordinates. That is, Taiwanese managers are more likely to show preferences to styles that maintain engagement, consensuses and harmony (e.g. consultative and participative) than autocratic or delegative styles.

\section{Method}

The questionnaire used in this study was comprised of three sections. The first section provides a basic profile of the firm (e.g. sector of enterprise, job, sex, age). The second section deals with decision styles. This scale (Ali, 1989) has six statements pertaining to autocratic, pseudo consultative, consultative, participative, pseudo participative (i.e. allowing subordinates to participate in discussions, although final decisions are the leader's prerogative), and delegative styles. Ali (1989) and Amirshahi (1998) determined that this scale relates to selected managerial work values and satisfactions.

The third section of the questionnaire encompasses I/C measures. The measures include the following:

Work Individualism Scale. The scale (Ali, 1988) contains seven items and measures individualism in the workplace. It emphasises self-reliance as a source of success, individual rather than group rewards, pride in accomplishments, loyalty to self and family, and loyalty to supervisors in the workplace. The statements were rated on a five-point Likert-type scale.

Individualism Scale. The Individualism scale (Triandis, 1990) focuses on self-reliance, self-fulfillment, and independence. The scale is based on a construct developed by Hui (1984) and is reliable and valid (Triandis, Bontempo, Villareal, Asai \& Lucca, 1988). The statements were rated on a five-point Likert-type scale.

Work Collectivism Scale. This scale is a modified version of the sociocentric value of Flowers, et al. (1975). Ali $(1982,1988)$ has used this scale in the Arab world and Amirshahi (1998) has used it in Iran. Both researchers found it reliable. A five-point Likert-type scale was used to rate statements.

Collectivism Belief Scale. This scale is a modified version of Buchholz (1977). The scale has been widely used in national and cross-cultural studies and found to be valid. The participants rated each statement on a five-point Likert-type scale.

\section{Sample and Procedures}

To avoid problems associated with mailing questionnaires in Taiwan and to maximise the response, personal distribution was adopted. About 600 questionnaires were distributed directly to employees with managerial positions in private, public, and mixed enterprises in the capital, Taipei. 260 questionnaires were returned and deemed usable. The response rate was $43 \%$. 
The survey was conducted in Mandarin. Prior to collecting data from the Taiwanese managers, careful attention was given to maintaining the accuracy in the translation of the survey statements. Two bilingual Taiwanese independently converted the English version to Mandarin. They then met with a third person and finalised the questionnaire.

$71 \%$ of the participants in this study were male; $91 \%$ worked in the private sector. Most of the participants were middle and top-level managers (90\%) and $59 \%$ were less than 40 years old.

\section{Results}

Frequency distribution, one-way analysis of variance (ANOVA) and one-way multivariate analysis of variance (MANOVA) were used in this analysis. The results of the frequency distribution are presented in Table 1 . The results show that Taiwanese preferred consultative (52\%) and participative styles $(23 \%)$ and that the least preferred styles were pseudo-consultative (5\%) and delegative (4\%). The participants were asked, too, to indicate the style they practiced, believed most effective, and the style most often used by their immediate supervisors. Participants considered consultative style as the most practiced (52\%) and effective (37\%) followed by participative (26\% and $25 \%$ respectively). In terms of the style of their immediate supervisors, the participants believed that their supervisors were mostly consultative (35\%) and autocratic (21\%). In terms of the most effective style, participants thought that the consultative style is the most effective (35\%); this is a noticeable drop from about the $53 \%$ in the category of preferred or practiced consultative style.

The MANOVA results are presented in Table 2. The results show that there were no significant differences across sectors of enterprise. Managers relative to non-supervisor subjects scored high on work collectivism ( $X=4.00$ vs. $X=3.68$; $\mathrm{F}=2.47, \mathrm{p}<.05)$ and on collectivism belief $(\mathrm{X}=3.77$ vs. $\mathrm{X}=3.56 ; \mathrm{F}=2.16, \mathrm{p}$ $<.05$ ). The results of one-way analysis of variance (ANOVA) of work collectivism measures, for example, demonstrate that managers scored highly and significantly on statements that underscore the role of the group in organisational life (see Table 3).

Furthermore, male participants scored higher than females on collectivism belief ( $\mathrm{X}=3.82$ vs. $\mathrm{X}=3.70 ; \mathrm{F}=2.47, \mathrm{p}<.05$ ). Likewise older participants (40 years and over) scored significantly higher than younger participants on both work collectivism $(\mathrm{X}=4.07 \& 4.08$ vs. $\mathrm{X}=3.62 \& 3.94, \mathrm{~F}=1.48, \mathrm{p}<.05)$ and collectivism belief $(X=3.87 \& 3.86$ vs. $X=3.56 \& 3.60, F=1.68, p<.05)$. In terms of the preferred style, those who were autocratic and pseudo-consultative scored higher than those who preferred other styles on individualism $(\mathrm{F}=1.86, \mathrm{p}$ $<.01)$. 


\begin{tabular}{|c|c|c|c|c|}
\hline & Proforred & & & \\
\hline $\begin{array}{c}\text { Autocratic } \\
\mathrm{N} \\
\% \\
\end{array}$ & $\begin{array}{r}11 \\
5 \\
\end{array}$ & $\begin{array}{c}12 \\
5 \\
\end{array}$ & $\begin{array}{l}27 \\
11 \\
\end{array}$ & $\begin{array}{l}54 \\
21 \\
\end{array}$ \\
\hline $\begin{array}{c}\text { Pseudo-consultative } \\
\mathrm{N} \\
\% \\
\end{array}$ & $\begin{array}{l}4 \\
2 \\
\end{array}$ & $\begin{array}{l}6 \\
2 \\
\end{array}$ & $\begin{array}{c}10 \\
4 \\
\end{array}$ & $\begin{array}{l}41 \\
15 \\
\end{array}$ \\
\hline $\begin{array}{c}\text { Consultative } \\
\mathrm{N} \\
\% \\
\end{array}$ & $\begin{array}{c}127 \\
53 \\
\end{array}$ & $\begin{array}{c}131 \\
52 \\
\end{array}$ & $\begin{array}{l}94 \\
37\end{array}$ & $\begin{array}{l}88 \\
35 \\
\end{array}$ \\
\hline $\begin{array}{c}\text { Participative } \\
\mathrm{N} \\
\% \\
\end{array}$ & $\begin{array}{l}54 \\
23 \\
\end{array}$ & $\begin{array}{l}66 \\
26 \\
\end{array}$ & $\begin{array}{l}65 \\
25 \\
\end{array}$ & $\begin{array}{l}28 \\
11 \\
\end{array}$ \\
\hline $\begin{array}{c}\text { Pseudo-participative } \\
\text { N } \\
\% \\
\end{array}$ & $\begin{array}{l}33 \\
13 \\
\end{array}$ & $\begin{array}{l}26 \\
10 \\
\end{array}$ & $\begin{array}{l}51 \\
20 \\
\end{array}$ & $\begin{array}{l}32 \\
13 \\
\end{array}$ \\
\hline $\begin{array}{c}\text { aspnumDelegative } \\
\mathrm{N} \\
\% \\
\end{array}$ & $\begin{array}{l}9 \\
4 \\
\end{array}$ & $\begin{array}{c}12 \\
5 \\
\end{array}$ & $\begin{array}{l}8 \\
3 \\
\end{array}$ & $\begin{array}{c}12 \\
5 \\
\end{array}$ \\
\hline $\begin{array}{l}\text { Total } \\
N \\
\%\end{array}$ & $\begin{array}{l}238 \\
100\end{array}$ & $\begin{array}{l}253 \\
100\end{array}$ & $\begin{array}{l}255 \\
100\end{array}$ & $\begin{array}{l}255 \\
100\end{array}$ \\
\hline
\end{tabular}

\begin{tabular}{|l|c|c|c|c|c|}
\hline \multicolumn{7}{|c|}{ Table 2: MANOVA Test for I/C Measures by Selected Variables } \\
\hline Variable & $\mathrm{N}$ & $\begin{array}{c}\text { Work } \\
\text { Collectivism }\end{array}$ & $\begin{array}{c}\text { Collectivism } \\
\text { Belief }\end{array}$ & $\begin{array}{c}\text { Work } \\
\text { Individualism }\end{array}$ & Individualism \\
\hline Sector & 15 & 3.97 & 3.73 & 3.62 & 3.01 \\
Public & 233 & 3.96 & 3.74 & 3.62 & 3.03 \\
Private & 8 & 3.97 & 4.08 & 3.63 & 2.82 \\
Mixed & & 0.889 & 1.282 & 1.408 & 0.700 \\
\hline F & 231 & 4.00 & 3.77 & 3.62 & 3.02 \\
\hline Job & 25 & 3.68 & 3.56 & 3.61 & 3.09 \\
Manager & & $2.474^{*}$ & $2.167^{\star}$ & 0.520 & 0.532 \\
Non-supervisory & & & & & 3.05 \\
\hline F & 183 & 4.01 & 3.82 & 3.65 & 2.99 \\
\hline Sex & 73 & 3.79 & 3.70 & 3.55 & 1.203 \\
\hline Male & & 1.438 & $2.488^{*}$ & 1.786 & \\
\hline Female & & & & \\
\hline F & & & & & \\
\hline
\end{tabular}




\begin{tabular}{|l|c|c|c|c|c|}
\hline Age & & & & & \\
Less than 30 & 24 & 3.62 & 3.56 & 3.58 & 3.13 \\
$30-39$ & 128 & 3.94 & 3.60 & 3.59 & 3.01 \\
$40-49$ & 79 & 4.07 & 3.87 & 3.63 & 3.06 \\
50 and over & 25 & 4.08 & 3.86 & 3.76 & 2.95 \\
\hline F & & $1.485^{*}$ & $1.682^{*}$ & 1.214 & 1.111 \\
\hline Preferred & & & & & \\
Decision Styles & & & & & 3.40 \\
Autocratic & 11 & 3.87 & 3.61 & 3.68 & 3.50 \\
Pseudo-Consult & 4 & 3.80 & 3.60 & 3.61 & 3.03 \\
Consultative & 127 & 4.00 & 3.75 & 3.60 & 2.99 \\
Participative & 54 & 4.09 & 3.86 & 3.63 & 2.97 \\
Pseudo-Part & 33 & 3.96 & 3.77 & 3.76 & 3.04 \\
Delegative & 9 & 3.58 & 3.59 & 3.52 & $1.86^{* *}$ \\
\hline F & & 1.28 & 1.03 & $1.61^{* *}$ & \\
\hline * P < .05 * P < .01 & & & & \\
\hline
\end{tabular}

Table 3: One-Way Analysis of Variance (ANOVA) of Work Collectivism by Job Position

\begin{tabular}{|l|l|c|c|c|}
\hline & \multicolumn{1}{|c|}{ Statement } & $\begin{array}{c}\text { Mean for } \\
\text { Managers }\end{array}$ & $\begin{array}{c}\text { Mean for } \\
\text { Non-Supervisor } \\
\text { Managers }\end{array}$ & F Value \\
\hline 1. & $\begin{array}{l}\text { Working in a group is better than working } \\
\text { alone }\end{array}$ & 4.25 & 4.12 & .66 \\
\hline 2. & $\begin{array}{l}\text { Better decisions are made in a group than by } \\
\text { individuals }\end{array}$ & 3.74 & 3.48 & 2.02 \\
\hline 3. & $\begin{array}{l}\text { It is best to have a job as part of an organisa- } \\
\text { tion where all work together, even if you do not } \\
\text { get individual credit }\end{array}$ & 3.92 & 3.36 & $6.88^{*}$ \\
\hline 4. & $\begin{array}{l}\text { One should work hard to improve the status of } \\
\text { one's work group, even if it means sacrificing } \\
\text { some individual credit }\end{array}$ & 3.85 & 3.24 & $11.15^{*}$ \\
\hline 5. & Complying with group beliefs is a virtue & 4.21 & 3.76 & $9.22^{*}$ \\
\hline 6. & $\begin{array}{l}\text { The group is the most important entity in any } \\
\text { organisation }\end{array}$ & 4.26 & 3.84 & $10.59^{*}$ \\
\hline 7. & $\begin{array}{l}\text { One's contributions to the group is the most } \\
\text { important thing about one's work }\end{array}$ & 4.06 & 3.48 & $7.31^{*}$ \\
\hline 8. & $\begin{array}{l}\text { Work is necessary to have and develop close } \\
\text { friendships }\end{array}$ & 3.95 & 3.48 & $7.31^{*}$ \\
\hline 9. & Work is a means to foster group interest & 4.19 & 4.12 & .28 \\
\hline
\end{tabular}




\begin{tabular}{|c|l|c|c|c|}
\hline 10. & $\begin{array}{l}\text { The approval of my work by my peer groups } \\
\text { and associates is not very valuable to me** }\end{array}$ & 3.41 & 3.50 & .26 \\
\hline 11. & $\begin{array}{l}\text { It is not necessary to protect my work group } \\
\text { and be proud of its achievement** }\end{array}$ & 4.14 & 4.08 & .10 \\
\hline$* P<.00 \quad * \star$ Reversed Score
\end{tabular}

\section{Discussion}

Identifying decision styles and individualism - collectivism orientation in Taiwan is a vital task for understanding management and organisation in a society that has experienced rapid industrial development. In fact, the results of this study contribute to the ongoing organisational debate on societal transformation and the nature of social changes in Taiwan. As indicated earlier, studies that address whether or not the Taiwanese society is collectivist or individualistic provide contradictory results. Some have asserted that the society is experiencing a deep social transformation, away from collectivism and toward individualism. On the other hand studies which have found that collectivism is a deeply held belief tend to underscore the process of value transmission from parent's generation to child's generation.

The fact that participants in this study are more inclined toward collectivism rather than individualism provides support to the research that argues that despite the economic development, which has been taking place in Taiwan since early 1970, the society in general still espouses Chinese collectivism orientation. Such a result stands in sharp contrast to other studies that assert that members of the new business and professional generation are committed to individualism (see Yu \& Miller, 2003; Wu, 2004). This result should be viewed in the context of the nature of cultural values. Researchers have accentuated the fact that cultural values are not prone to rapid changes. In Taiwan, this fact is reinforced by two realities. First, Taiwanese society is characterised by sets of intimate and overlapping social networks that help to sustain traditions, personal and professional relationships and ultimately shape aspirations and orientations. Second, Taiwan is a society that experiences political uncertainty and constant fear of possible threat coming from Mainland China. It is likely that this fear not only strengthens Taiwanese identity, but also cohesiveness and the feeling of shared destiny. Ironically, this state of fear and uncertainty about the future induces self-reliance and independent thinking. Perhaps this explains the existence of moderate inclination among participants toward individualism. That is, the emergence of moderate individualism constitutes an attempt to underscore the importance of "self" in a society that has historically valued groups and group activities. There is evidence in the relatively high scores on two statements in the work individualism measure which accentuates individual interests and that a person is the ultimate arbiter of his/her interest - "One's loyalty should be first and foremost to himself and his family; $\mathrm{X}$ $=4.25$ " and "A man is the best judge of his own best interest; $\mathrm{X}=3.69$." 
Managers who supervise others relative to those without direct subordinates working with them showed higher inclination for collectivism. This result may seem startling. Nevertheless, the nature of groups and work orientation in Taiwan helps to highlight two possible explanations. The first is general, as managers' jobs encompass coordination, cooperation and integration. These activities require group interaction and sensitivity to the welfare of subordinates in a society that is characterised by social cohesiveness and the existence of multiple sets of social networks. Furthermore, there is something peculiar to the Chinese culture, but with significant organisational value. In both family and business organisations, senior members in the hierarchy place high value on obedience and consider it not only a manifestation of loyalty, but also a positive behaviour (Yi, et al., 2004). Indeed, serving a leader unreservedly without complaints is an honourable act of integrity and loyalty (Chi, 1999).

Older participants, 40 years and up, displayed higher tendencies toward collectivism than other age groups. There were, however, no significant differences across age groups on individualism measures. Two plausible justifications exist. The first is that the older generation is usually at ease and comfortable with traditional collectivism. This generation is not only capable of internalising the shared societal values, but also play the role of the "guardian" of what is regarded as cherished and noble in the society. It is this generation that keeps the tansmission of tradition alive. Second, the younger generation's slight display of collectivism is more likely to become stronger as years pass by. While this phenomenon is almost universal, its existence, however, is pervasive in traditional high context cultures. It is in these cultures that members of the society share many deeply held values and norms.

In terms of decision styles, participants showed high preferences for consultative and participative styles. Furthermore, participants appear not only to prefer, but also to practice consultative and participative styles and consider them as the most effective. These results are consistent with the traditional orientation toward group and group involvement in decision-making. More importantly, they are in line with the proposition that in collective cultures, leaders and managers espouse approaches and styles that maintain harmony and consensuses. The results provide evidence that deep, cultural tendencies, despite economic progress, exercise influence on decision-making orientations. Indeed, the absence of differences in collectivism measures across preferred decision styles reaffirms cultural inclination toward collective orientations. Differences on individualism, along preferred decision styles, however, may indicate that individualism is not yet commonly shared.

In conclusion, the results suggest that collectivism orientation and consultative and participative decision styles relatively more than individualism and autocratic tendencies exist among Taiwanese managers. These results underscore the importance of culture and its impact on management processes. The results, how- 
ever, raise questions regarding the relationships among management, culture, and industrial development. In particular, the results show that collectivism and some individualistic tendencies exist simultaneously and that Taiwanese managers tend to exhibit what seem to be contradictory qualities. Perhaps, industrial development, which sustains individualistic tendencies especially pursuing self-interest, has not yet eroded Chinese collective values and norms. While the result is not conclusive, because of the small sample size, it does shed light on the nature of transformation and general management orientation in Taiwan. 


\section{References}

Ali, Abbas (1982) An empirical investigation of managerial value systems for working in Iraq. Unpublished Doctoral Dissertation, West Virginia University.

Ali, Abbas (1988) "Islamic work ethic in Arabia." Journal of Social Psychology, 126(5), pp.507-519.

Ali, Abbas (1989) "Decision style and work satisfaction of Arab Gulf Executives: A cross-national study." International Studies of Management and Organization, 19(2), pp.22-37.

Ali, Abbas (1993) "Decision-making style, individualism, and attitudes toward risk of Arab executives." International Studies of Management and Organization, 23(3), pp.53-74.

Ali, Abbas (2004) Islamic perspectives on management and organization. London: Edward Elgar.

Ali, Abbas, Azim, A. and Falcone, T. (1993) "Work loyalty and individualism in the United States and Canada." International Journal of Manpower, Vol. 14(6), pp.58-66.

Ali, Abbas, Taqi, A. and Krishanan, K. (1997) "Individualism, Collectivism, and Decision Styles of Management in Kuwait." Journal of Social Psychology, Vol. 137(95), pp.629-637.

Amirshahi, M. (1998) Empirical study of managerial work values systems and decision making styles among managers in Iran. Unpublished Ph.D. dissertation. Perth, Western Australia: Curtin University.

Blyton, P. (1984) "Some old and new problems in employee participation in decision making." International Social Science Journal, 37(2), pp.217-231.

Bond, M., Leung, K. and Wan, K. (June 1982) "How does cultural collectivism operate?" Journal of Cross-Cultural Psychology, 13(2), pp.186-201.

Buchholz, R.A. (1977) "The belief structure of managers relative to work concepts measures by a factor analytic model." Personnel Psychology, 30, pp.567-587.

Chi, Shu-Cheng (1999) "The role of Chin-Shins of top managers in Taiwanese organizations: Exploring Chinese leadership phenomena." In Kao, S., Sinha, D. and Wilpert, B. (Eds.) Management and Cultural Values (pp.252-264). New Delhi: Sage Publications.

Choi, I., Nisbett, R. and Norenzayan, A. (1999) "Causal attribution across cultures: Variation and universality." Psychological Bulletin, Vol. 125(1), pp.47-63. 
Economist Intelligence Unit (2004) Taiwan. Available: www.eiu.com

England, G., Negandhi, A. and Wilpert, B. (1979) Organizational functioning in a cross-cultural perspective. Kent, Ohio: Kent State University.

Flowers, V., Hughes, C., Myers, M. and Myers, S. (1975) Managerial values for working: An AMA survey report. New York: American Management Association.

Heller, F. and Wilpert, B. (1979) "Managerial decision making: An international comparison." In England, G., Negandhi, A. and Wilpert, B. (1979) Organizational functioning in a cross-cultural perspective (pp.49-72). Kent, Ohio: Kent State University.

Hofstede, G. (1980) Culture's consequences: International differences in work-related values. Beverly Hills: Sage.

Hofstede, G. (1983) "The cultural relativity of organizational practices and theories.” Journal of International Business Studies, 14(2), pp.75-90.

Hofstede, G. (1994) "The business of international business is culture." International Business Review, Vol. 3(1), p.114.

Hofstede, G. (1999) "Problems remain, but theories will change: The universal and the specific in $21^{\text {st }}$ century global management." Organizational Dynamics, 28(1), pp.34-43.

Hui, C. (1984) Individualism-collectivism: Theory, measurement and its relationship to reward allocation. Unpublished doctoral dissertation, University of Illinois.

Hui, C. (1988) "Measurement of individualism-collectivism." Journal of Research on Personality, 22, pp.17-36.

Ji, Li-Jun, Nisbett, R. and Peng, K. (2000) "Culture, control, and perception of relationships in the environment." Journal of Personality and Social Psychology, Vol. 78(5), pp.943-955.

Kim, U. (1994) "Individualism and collectivism." In U. Kim, H. Triandis, C. Kagitcibasi, S. Choi and G. Yoon (Eds.) Cross-Cultural Research and Methodology Series, 18 (pp.19-40). London: Sage Publications.

Kuo, S. and Liu, C. (1999) "The development of the economy of Taiwan." Asian-Pacific Economic Literature, Vol. 13(1), pp.36-49.

Lin, Y. and Szanberg, M. (1998) "Determinants of Taiwanese foreign direct investment 1965-1993." In Farok Contractor (Ed.) Economic Transformation in Emerging Countries (pp.85-102). Amsterdam: Elsevier. 
Markus, H. and Kitayama, S. (1991) "Culture and the self: Implications for cognition, emotion, and motivation." Psychological Review, Vol. 98(2), pp.224-253.

Oyserman, D., Coon, H. and Kemmelmeier, M. (2002) "Rethinking individualism and collectivism: Evaluation of theoretical assumptions and meta-analyses." Psychological Bulletin, 128(1).

Sinha, D., Kao, S. and Wilpert, B. (1999) "Introduction: The emergence of indigenization." In Kao, S., Sinha, D. and Wilpert, B. (Eds.) Management and Cultural Values (pp.19-28). New Delhi: Sage Publications.

Sinha, D. and Tripathi, R. (1994) "Individualism in a collectivist culture: A case of coexistence of opposites." In U. Kim, H. Triandis, C. Kagitcibasi, S. Choi and G. Yoon (Eds.) Cross-Cultural Research and Methodology Series, 18, pp.123-136.

Triandis, H. (1990) Individualism and Collectivism Manual. Champaign: University of Illinois.

Triandis, H. (2004) "The many dimensions of culture." The Academy of Management Executives, 18(1), pp.88-93.

Triandis, H., Bontempo, R., Villareal, M., Asai, M. and Lucca, N. (1988) "Individualism and collectivism: Cross-cultural perspectives." Journal of Personality and Social Psychology, 54(2), pp.323-338.

Wagner, J. and Moch, M. (1986) "Individualism-Collectivism: Concept and Measures." Group and Organization Studies, Vol. 11(3), pp.280-304.

Waterman, A. (1984) The Psychology of Individualism. New York: Praeger.

Williams, B. (2003) "The worldview dimensions of individualism and collectivism: Implications for counseling." Journal of Counseling and Development, 81(3).

Wu, Pei-Chuan (2004) "HRM in Taiwan." In P. Budhwar (Ed.) Managing Human Resources in Asia-Pacific (pp.93-112). London: Routledge.

Yi, Chin-Chun, Chang, Chin-Fen, and Chang, Ying-hwang (2004) "The intergenerational transmission of family values: A comparison between teenagers and parents in Taiwan." Journal of Comparative Family Studies, Vol. 35(4), pp.524-545.

Yu, Hui-Chun and Miller, P. (2003) "The generation gap and cultural influence: A Taiwan empirical investigation." Cross Cultural Management, Vol. 10(3), pp.23-41. Yukl, G. (2002) Leadership in Organization. Englewood Cliffs, NJ: Prentice-Hall. 